\title{
Comparative Study of the Subsurface Thermal Structure in Northern Honshu, Japan, Based on Normalized Temperature Data and Solute Geothermometers
}

\author{
Yota Suzuki $^{1, *}$, Seiichiro Ioka ${ }^{2}$ and Hirofumi Muraoka ${ }^{2}$ \\ 1 Graduate School of Science and Technology, Hirosaki University, 3 Bunkyo-cho, Hirosaki, \\ Aomori 036-8561, Japan \\ 2 North Japan Research Institute for Sustainable Energy, Hirosaki University, 2-1-3 Matsubara, \\ Aomori 030-0813, Japan; ioka@hirosaki-u.ac.jp (S.I.); hiro@hirosaki-u.ac.jp (H.M.) \\ * Correspondence: h15ds204@hirosaki-u.ac.jp; Tel.: +81-17-735-3363; Fax: +81-17-735-5411
}

Academic Editor: Kamel Hooman

Received: 6 April 2016; Accepted: 6 May 2016; Published: 19 May 2016

\begin{abstract}
To promote geothermal development in Aomori Prefecture, Japan, this study compiled a database of the geothermal resources of the prefecture, which included chemical data for 786 hot springs, temperature data for 26 natural springs, and subsurface temperature data for 35 wells. A map of the activity index distribution for the entire prefecture was also developed using the Aomori Prefecture Geothermal Resource database, and its efficiency was discussed by comparison with the distribution of Quaternary volcanoes and the temperature distribution map calculated using quartz and Na-K solute geothermometers. The activity index distribution map for the entire prefecture showed a good fit with both the distribution map of a region with a sharp eastern edge of low-velocity zones in the mantle wedge and the volcanic front, as well as the temperature distribution map calculated using the quartz and Na-K geothermometers. This reflected the effectiveness of the developed map, which indicated the Hakkoda-san and Hiuchi-dake areas as promising for geothermal development. Given that the activity index distribution map is easy to use, it could become a method of assessment, in conjunction with temperature distribution maps calculated using solute geothermometers, for detecting promising areas in the early stages of geothermal exploration.
\end{abstract}

Keywords: geothermal energy; geothermal exploration; geothermal mapping; geothermal database; geothermometry; volcanic front; activity index

\section{Introduction}

The need for greater use of renewable energy has increased in Japan following the Great East Japan Earthquake that occurred on 11 March 2011. Geothermal energy has an advantage as the only stable source of power among the available renewable energies. Japan ranks third in the world in terms of available geothermal resources; however, these resources have not been utilized effectively and as of the end of 2015, the total capacity of installed geothermal power plants in Japan ranked only ninth in the world [1]. Much of Japan's geothermal resources are concentrated in the Hokkaido, Tohoku, Chubu, and Kyushu regions [2], and as of the end of 2014, seven of the 18 geothermal plants operating in Japan were located in the Tohoku area [3].

Aomori Prefecture, located within the Tohoku region, is home to several Quaternary volcanoes and calderas (Figure 1) as well as abundant hot springs [4]. Although several geothermal development surveys have been conducted in the past around these Quaternary volcanoes and calderas [5-8], no geothermal plants have been built for lack of identification. In order to contribute to the construction 
of geothermal plants within the prefecture, the objective of this study was to build the Aomori Prefecture Geothermal Resource database by compiling chemical data for 786 hot springs, temperature data for 26 natural hot springs, and subsurface temperature data for 35 wells, and to develop an assessment map for areas with geothermal potential across the Prefecture.

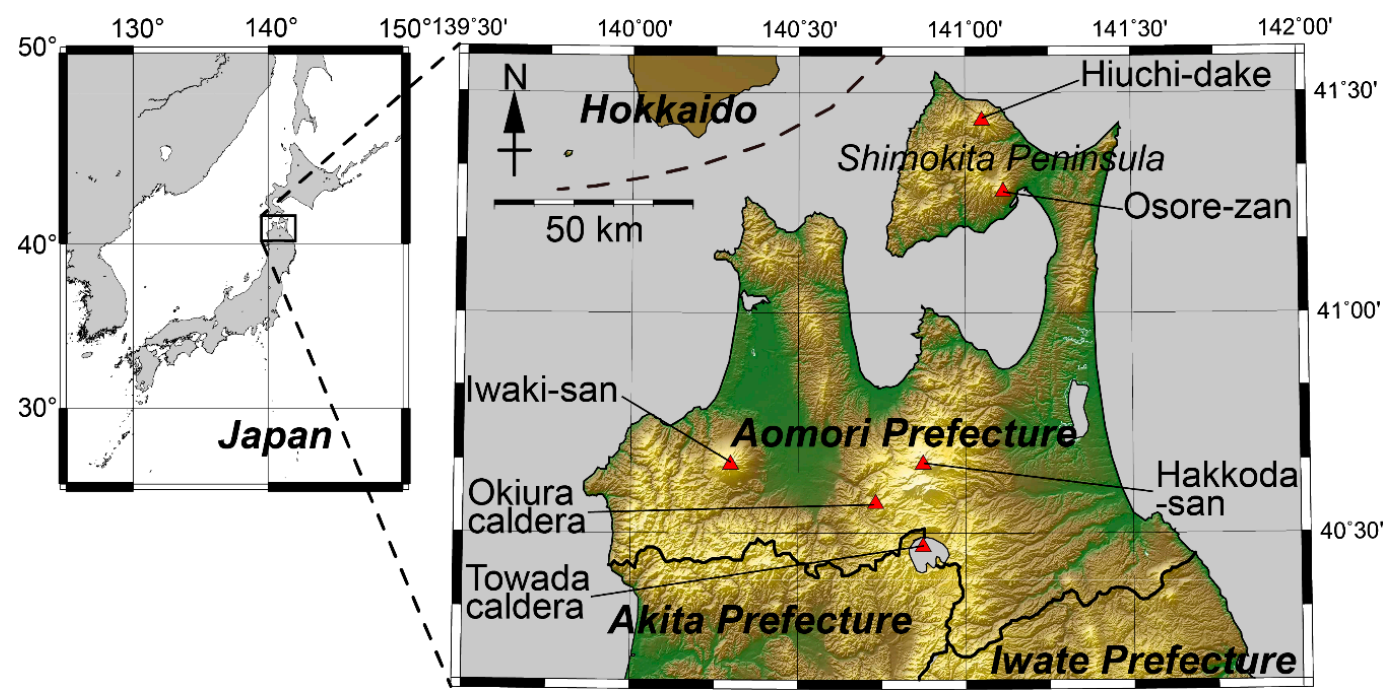

Figure 1. Topographic summary of Aomori Prefecture, Japan. Red triangles indicate the locations of major Quaternary volcanoes and calderas. Map is based on a $10 \mathrm{~m}$-mesh digital elevation model developed by the Geospatial Information Authority of Japan.

A solute geothermometer is a method for estimating the geothermal reservoir temperature from the chemical data of hot springs, and it is an important tool in the early stages of geothermal exploration. Determining the estimated temperature distribution is necessary when assessing the geothermal development potential of an area. In addition, the activity index [9] has also been reported effective in Aomori Prefecture for estimating the subsurface thermal structure around the Hakkoda-san area and Shimokita Peninsula [10]; however, a distribution map of the activity index for the entire prefecture has yet to be developed. Therefore, this study developed an activity index distribution map for the entire prefecture, compared it with the distribution of Quaternary volcanoes and temperature calculated based on solute geothermometer measurements, evaluated the effectiveness of the developed map, and attempted an assessment of areas with potential for geothermal development within the prefecture. Solute geothermometers were used for the comparison after those capable of estimating reservoir temperatures with the highest precision across the prefecture were established.

\section{Geothermal Resource Database of Aomori Prefecture}

The Aomori Prefecture Geothermal Resource database consists of chemical data for 786 hot springs, temperature data for 26 natural hot springs, and subsurface temperature data for 35 wells obtained from the "Atlas of Hydrothermal Systems in Japan" [11] and the "Record of Hot Spring Geology in Aomori Prefecture" [12]. The former is a collection of chemical data for 7203 hot springs and subsurface temperature data for 3066 wells across Japan, which was published in 2009 as a digitized CD-ROM [13]. Chemical data for 378 of the hot springs and subsurface temperature data for 35 of the wells were included in the Aomori Prefecture database. The latter contains spring temperatures, drilling depths, and chemical data for 408 hot springs, and discharge temperatures for 26 natural springs, which were also included in the Aomori Prefecture database.

The units of chemical concentration of the data collected for the database included both $\mathrm{mg} / \mathrm{kg}$ and $\mathrm{mg} / \mathrm{L}$, but this study treated values expressed as $\mathrm{mg} / \mathrm{kg}$ and $\mathrm{mg} / \mathrm{L}$ as approximately equal. 


\section{Subsurface Thermal Structure Based on the Activity Index}

The activity index is an indicator, proposed by Hayashi et al. [9], for the quantitative assessment of the temperature grade of geothermal wells and fields. It is based on the subsurface temperature of active geothermal areas increasing along the boiling curve of pure water with depths, and it has been used frequently in domestic geothermal developments [14,15]. The activity index can be calculated using the following equation:

$$
\text { Activity Index }=\frac{a}{b} \times 100=\left(1-\frac{T \mathrm{~b}-T \mathrm{~m}}{\mathrm{~Tb}-T \mathrm{~g}}\right) \times 100
$$

where $T \mathrm{~m}$ is the maximum temperature at the observed depth, $T \mathrm{~b}$ is the temperature as indicated by the boiling curve of pure water at the observed depth [16], $\mathrm{Tg}$ is the temperature derived from the average temperature gradient $\left(30^{\circ} \mathrm{C} / \mathrm{km}\right)$ at the observed depth. The activity index is thermally more active as the value approaches 100 . As the equation shows, $a$ is $T \mathrm{~m}-T \mathrm{~g}$ and $b \mathrm{is} \mathrm{Tb}-\mathrm{Tg}$. As an extreme case, it is noted that the activity index exists even when the depth is $0 \mathrm{~m}$ [15]. In this case, the activity index is either equivalent to the discharge temperature of the natural hot spring or it is the minimum value of the index.

Based on the Aomori Prefecture Geothermal Resource database, this study calculated and mapped the activity index values using data for 510 hot springs, temperatures for 26 natural hot springs, and bottom-hole temperatures for 35 wells, which had values available for spring temperature and drilling depth, both of which are needed for the calculation of the index. When calculating the activity index from hot spring data, the spring temperatures were assumed the maximum temperature at the given drilling depth, while spring temperatures for natural springs were assumed equal to the activity index. The map was developed using generic mapping tools (GMT) Version 4.5.9 (University of Hawaii at Manoa, Honolulu, HI, USA), and the contoured values were smoothed to 0.2-min intervals (approximately $370 \mathrm{~m}$ in the longitudinal direction) [17]. The tension factor was assumed 0.7 . The activity index distribution map for the prefecture revealed a tendency in which the index values were higher around Hakkoda-san area and the Shimokita Peninsula (Figure 2).

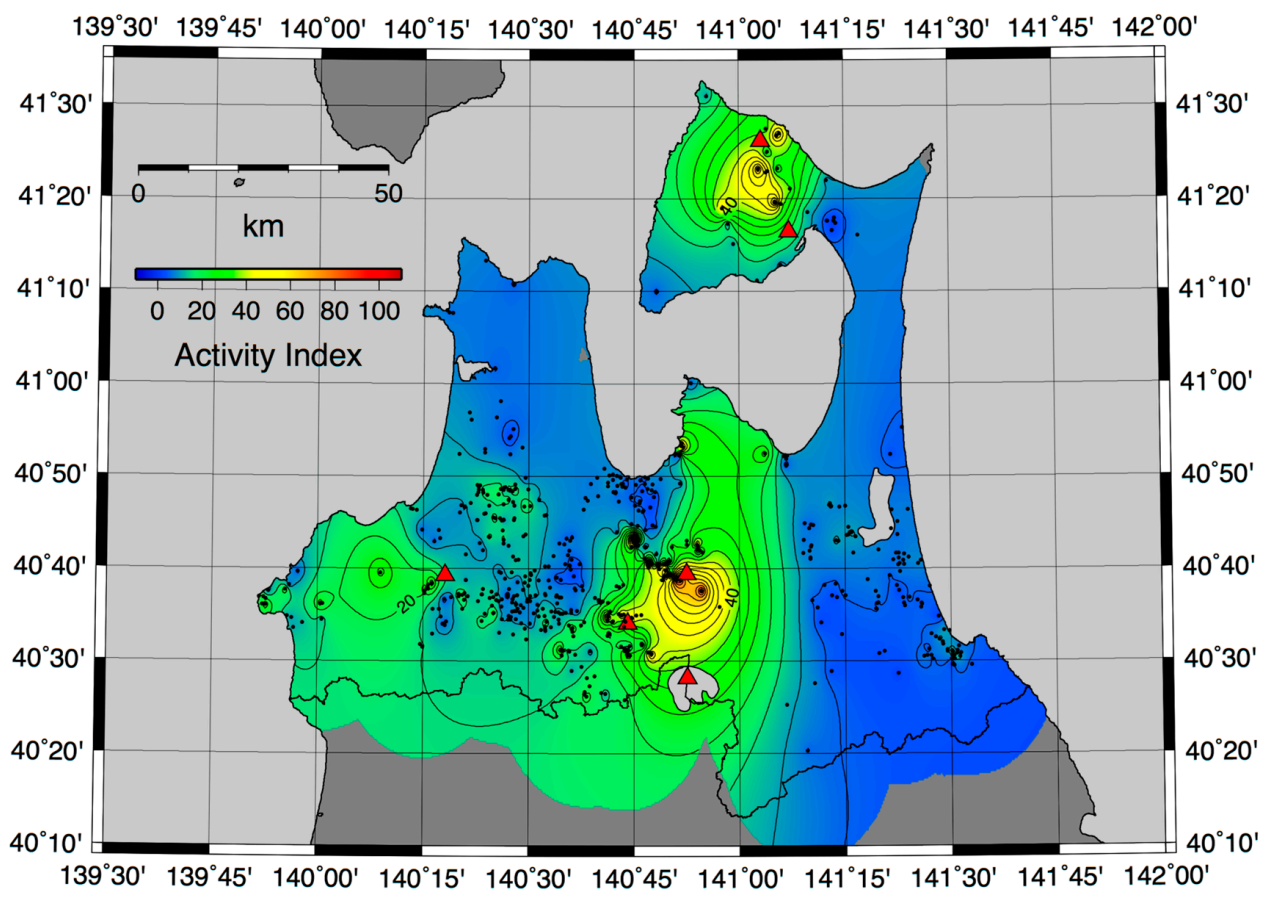

Figure 2. Activity index distribution map. Black dots indicate the data locations and red triangles indicate the locations of major Quaternary volcanoes and calderas. 


\section{Subsurface Thermal Structure Based on Solute Geothermometers}

Temperatures calculated from several solute geothermometers were compared for the purpose of selecting the geothermometers capable of estimating geothermal reservoir temperatures with the highest precision across the entire area of the Aomori Prefecture. The solute geothermometers used were the quartz conductive geothermometer [18], Na-K geothermometer [19], K-Mg geothermometer [19], Na-K-Ca geothermometer [20], and Na-K-Ca-Mg geothermometer [21] (Table 1). The results of the calculated temperatures are shown as isothermal lines in Figure 3.

Table 1. Major solute geothermometers used in this study.

\begin{tabular}{|c|c|c|}
\hline Geothermometer & Equations & References \\
\hline $\begin{array}{c}\text { Quartz (no steam loss) } \\
\text { (concentrations in mg/kg) }\end{array}$ & $t=\frac{1309}{5.19-\operatorname{logSiO} O_{2}}-273.15$ & $\begin{array}{l}\text { Fournier, } \\
1977[18]\end{array}$ \\
\hline $\begin{array}{c}\mathrm{Na}-\mathrm{K} \\
\text { (concentrations in } \mathrm{mg} / \mathrm{kg} \text { ) }\end{array}$ & $t=\frac{1390}{1.750+\log (\mathrm{Na} / \mathrm{K})}-273.15$ & $\begin{array}{l}\text { Giggenbach, } \\
1988 \text { [19] }\end{array}$ \\
\hline $\begin{array}{c}\mathrm{K}-\mathrm{Mg} \\
\text { (concentrations in } \mathrm{mg} / \mathrm{kg} \text { ) }\end{array}$ & $t=\frac{4410}{14.0-\log \left(\mathrm{K}^{2} / \mathrm{Mg}\right)}-273.15$ & $\begin{array}{l}\text { Giggenbach, } \\
1988 \text { [19] }\end{array}$ \\
\hline $\begin{array}{c}\mathrm{Na}-\mathrm{K}-\mathrm{Ca} \\
\text { (concentrations in mol/kg) }\end{array}$ & $\begin{array}{c}t=\frac{1647}{\log (\mathrm{Na} / \mathrm{K})+\beta(\log \sqrt{\mathrm{Ca}} / \mathrm{Na})+2.24}-273.15 \\
\beta=4 / 3 \text { for } \log (\sqrt{\mathrm{Ca}} / \mathrm{Na})>0 \wedge \mathrm{t}<100^{\circ} \mathrm{C} \\
\beta=1 / 3 \text { for } \log (\sqrt{\mathrm{Ca}} / \mathrm{Na})<0 \wedge \mathrm{t}>100^{\circ} \mathrm{C}\end{array}$ & $\begin{array}{c}\text { Fournier and Truesdell, } \\
1973 \text { [20] }\end{array}$ \\
\hline $\begin{array}{c}\mathrm{Na}-\mathrm{K}-\mathrm{Ca}-\mathrm{Mg} \\
\text { (concentrations in eq) }\end{array}$ & $\begin{array}{c}T_{\mathrm{NaKCaMg}}=T_{\mathrm{NaKCa}}-t_{\mathrm{Mg}} \\
R=\frac{\mathrm{Mg}}{\mathrm{Mg}+\mathrm{Ca}+\mathrm{K}} \times 100 \\
\text { For } 5<R<50 \\
\Delta t_{\mathrm{Mg}}=10.66-4.7415 R+325.87(\log R)^{2}- \\
1.032 \times 10^{5}(\log R)^{2} /\left(T_{\mathrm{NaKCaMg}}+273.15\right)- \\
1.968 \times 10^{7}(\log R)^{2} /\left(T_{\mathrm{NaKCa}}+273.15\right)^{2}+ \\
1.605 \times 10^{7}(\log R)^{3} /\left(T_{\mathrm{NaKCa}}+273.15\right)^{2} \\
\text { For } 0.5<R<5 \\
\Delta t_{\mathrm{Mg}}=-1.03+59.971 \log R+145.05(\log R)^{2}- \\
36711(\log R)^{2} /\left(T_{\mathrm{NaKCa}}+273.15\right)-1.67 \times \\
10^{7} \log R /\left(T_{\mathrm{NaKCa}}+273.15\right)^{2}\end{array}$ & $\begin{array}{l}\text { Fournier and Potter, } \\
1979[21]\end{array}$ \\
\hline
\end{tabular}

Data for the chemical analyses necessary for the calculations based on solute geothermometers were obtained from the Aomori Prefecture Geothermal Resource database. Because these values varied in their reliability, because they were analyzed using different methods by various analyzers and at different times, these data were used only if the ion balance, as calculated by Equation (2), was within $\pm 10 \%$ :

$$
\text { ion balance }(\%)=\frac{\Sigma \text { Cations }(m e q / l)-\Sigma \text { Anions }(m e q / l)}{\Sigma \text { Caitons }(m e q / l)+\Sigma \text { Anions }(\text { meq } / l)} \times 100
$$

The term $\Sigma$ Cations is the total amount of cations in the hot spring and $\Sigma$ Anions is the total amount of anions in the hot spring. However, data from the "Osore-zan hot spring" and "Sukayu hot spring" cited from the "Atlas of Hydrothermal Systems in Japan" were included as exceptions despite their ion balance being $-14 \%$ and $-17 \%$, respectively. They were included because, even though both springs had strong acidity of $\mathrm{pH}<3$, metal elements such as $\mathrm{Fe}$ and $\mathrm{Al}$, predomiantly available in acidic hot water, were not analyzed. This was assumed to be the reason why the ion balance values exceeded $\pm 10 \%$. Consequently, 713 data elements were used for the quartz conductive geothermometer, 733 for the Na-K geothermometer, 708 for the $\mathrm{K}-\mathrm{Mg}$ geothermometer, 717 for the $\mathrm{Na}-\mathrm{K}-\mathrm{Ca}$ geothermometer, and 540 for the Na-K-Ca-Mg geothermometer. Table 1 shows the equations for each of the geothermometers. 


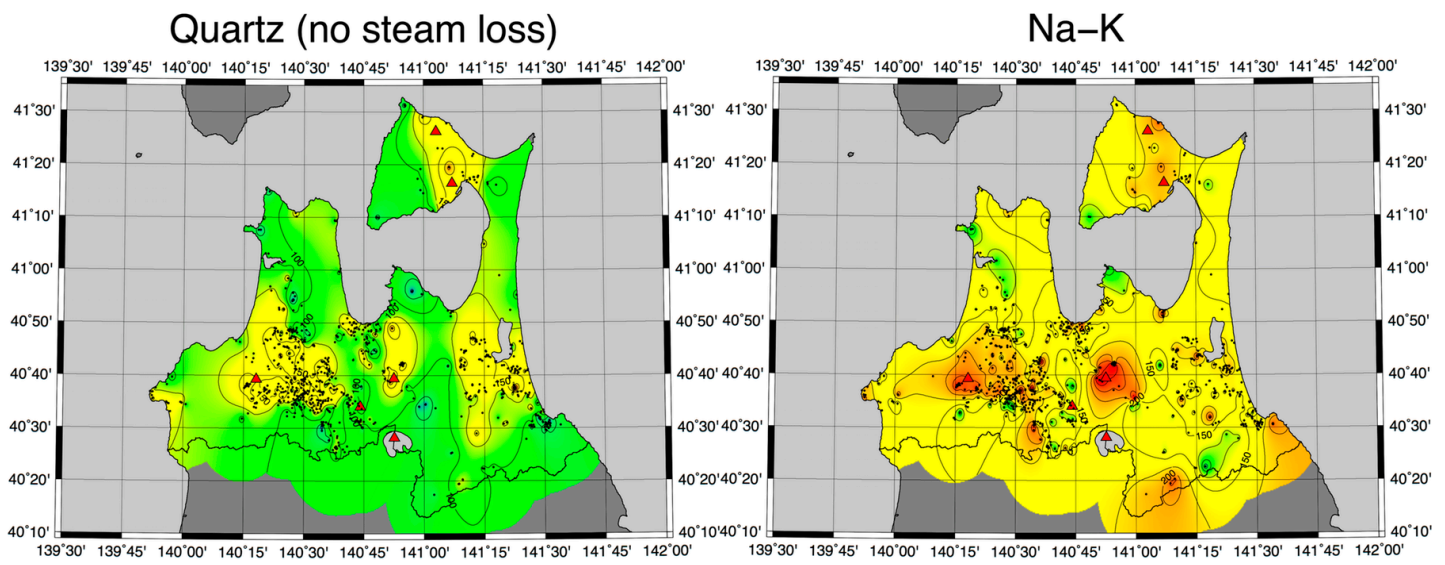

\section{$\mathrm{K}-\mathrm{Mg}$}

$\mathrm{Na}-\mathrm{K}-\mathrm{Ca}$
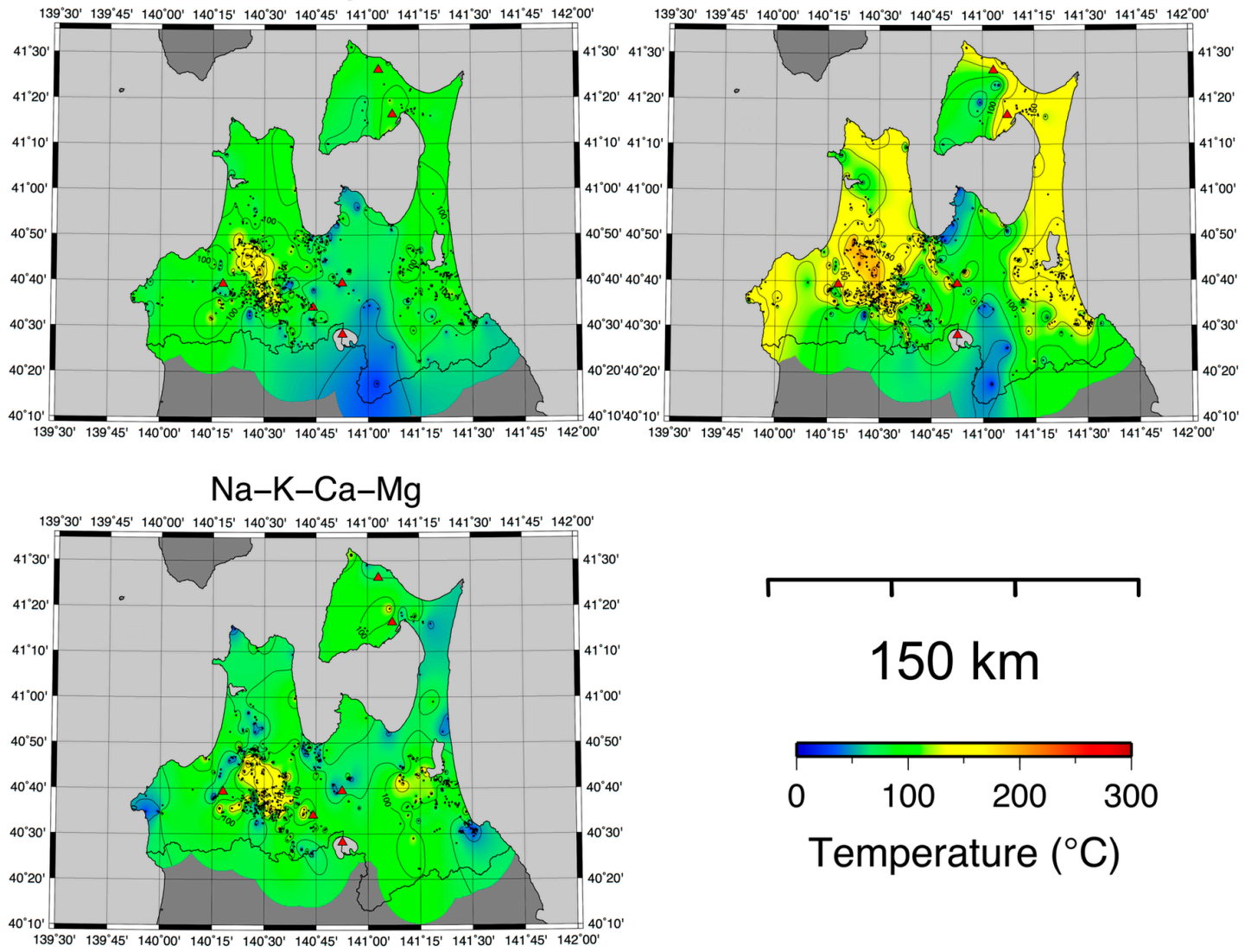

Temperature $\left({ }^{\circ} \mathrm{C}\right)$

Figure 3. Distribution maps for major solute geothermometers. Black dots indicate data locations and red triangles indicate the locations of major Quaternary volcanoes and calderas.

Isothermal lines were developed using GMT Version 4.5.9, where the values were smoothed and contoured at 0.2-min intervals (approximately $370 \mathrm{~m}$ in the longitudinal direction) [17]. Figure 3 shows the results where two major trends can be observed. The quartz geothermometer and Na-K geothermometer calculated higher temperatures in the Hakkoda-san area and the Shimokita Peninsula, which is a trend similar to that of the activity index distribution. Conversely, the $\mathrm{K}-\mathrm{Mg}$, Na-K-Ca, and $\mathrm{Na}-\mathrm{K}-\mathrm{Ca}-\mathrm{Mg}$ geothermometers calculated lower temperatures in these two areas. 


\section{Discussion}

\subsection{Reliability of Solute Geothermometers}

Solute geothermometers have been used frequently in geothermal developments because they can be used to estimate the subsurface temperature from chemical data alone. However, caution must be exercised because the results are expressed using a simple equation based on a few assumptions, e.g., the point of reaching an equilibrium at the geothermal reservoir is assumed conserved until discharge at the ground surface [18]. Therefore, this study considered the precision of major solute geothermometers by comparing the geothermal reservoir temperatures estimated by the geothermometers and the discharge temperatures of the hot springs. Figure 4 plots spring temperatures on the vertical axis and geothermal reservoir temperatures, estimated by the geothermometers, on the horizontal axis. Generally, reservoir temperatures should be higher than the discharge temperatures of the hot springs because of the geothermal gradient. Therefore, solute geothermometers that estimated reservoir temperatures that were lower than the discharge temperatures can be considered unlikely to be able to estimate reservoir temperatures with great accuracy.
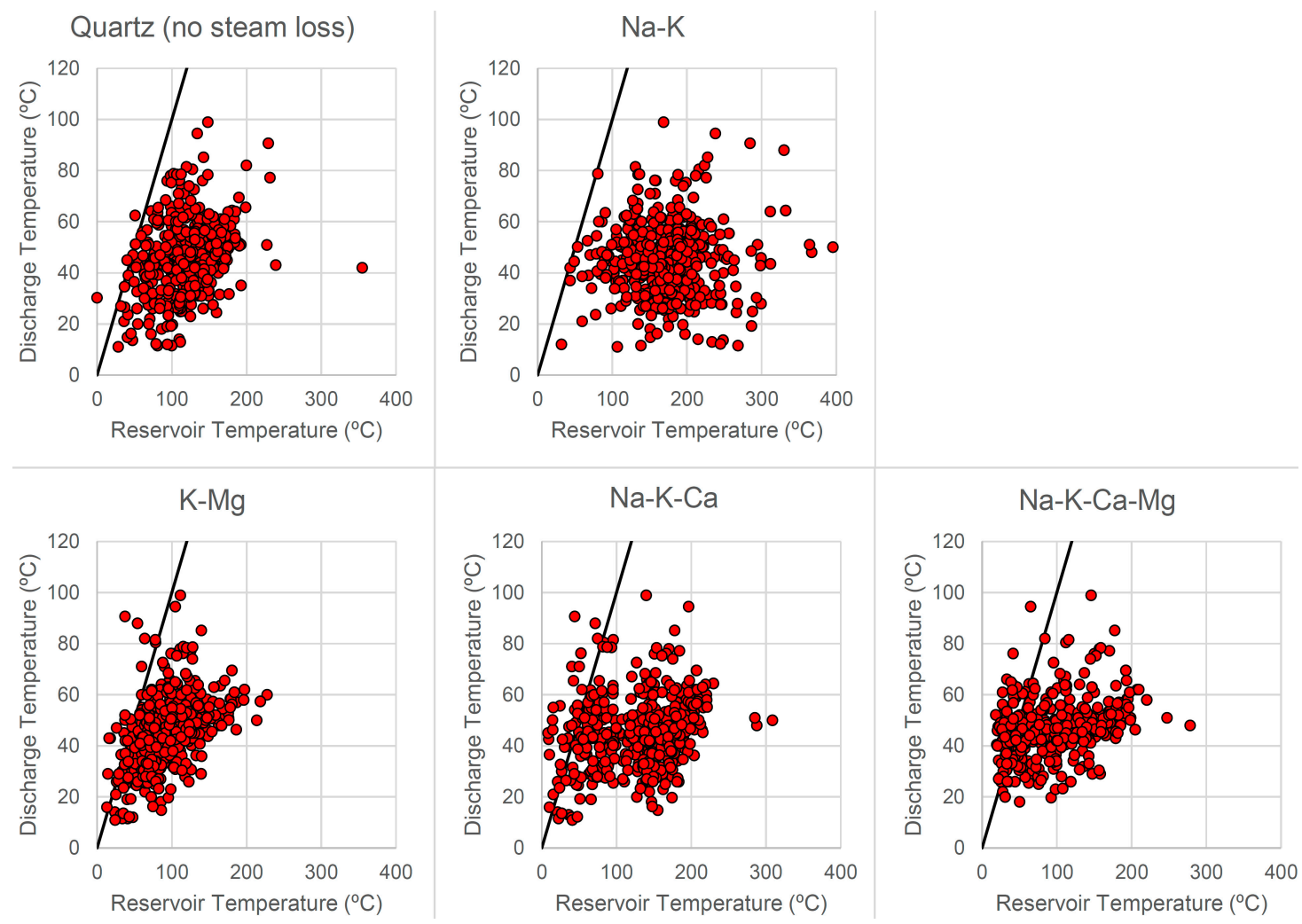

Figure 4. Comparison of major solute geothermometers and spring temperatures. Horizontal axis plots the reservoir temperatures estimated by the geothermometers and the vertical axis plots the discharge temperatures of the hot springs. Black line indicates the linear $y=x$ line.

Table 2 shows the number of low-accuracy data and their ratio for each of the solute geothermometers. The ratio of low-accuracy data was $0.7 \%$ for quartz, $0 \%$ for $\mathrm{Na}-\mathrm{K}, 2.8 \%$ for $\mathrm{K}-\mathrm{Mg}$, $5.7 \%$ for $\mathrm{Na}-\mathrm{K}-\mathrm{Ca}$, and $16.1 \%$ for $\mathrm{Na}-\mathrm{K}-\mathrm{Ca}-\mathrm{Mg}$. The results suggested that the quartz and $\mathrm{Na}-\mathrm{K}$ geothermometers, both of which had fewer low-accuracy data, were the solute geothermometers most capable of estimating geothermal reservoir temperatures with high precision in Aomori Prefecture. This conclusion was also supported by the fact that the K-Mg, Na-K-Ca, and Na-K-Ca-Mg geothermometers indicated lower temperatures than expected for the Quaternary volcano areas. 
Table 2. Total number of data used for the calculation by the major solute geothermometers, total number of low-accuracy data, and the ratio of low-accuracy data. Low-accuracy data indicate data in which reservoir temperatures estimated by the geothermometers were lower than the spring temperatures.

\begin{tabular}{cccccc}
\hline Geothermometer & Quartz (No Steam Loss) & Na-K & K-Mg & Na-K-Ca & Na-K-Ca-Mg \\
\hline Total number of data & 713 & 733 & 708 & 717 & 540 \\
Total number of low-accuracy data & 5 & 0 & 20 & 41 & 87 \\
Ratio of low-accuracy data & $0.7 \%$ & $0 \%$ & $2.8 \%$ & $5.7 \%$ & $16.1 \%$ \\
\hline
\end{tabular}

\subsection{Reliability of the Activity Index Map}

The Tohoku region, including the Aomori Prefecture, is located along the Japan Trench, where the Pacific Plate subducts beneath the North American Plate and volcanoes form a belt-like front parallel to the trench. Based on a detailed subsurface velocity structure, determined by applying seismic tomography beneath the Northeastern Japan arc, Nakajima et al. [22] identified a sheet-like low-velocity zone inclined nearly parallel to the plate boundary, which ranges from about 100-150-km depth to the Moho discontinuity within the mantle wedge. Furthermore, Hasegawa et al. [23] indicated that the distribution of Quaternary volcanoes matched the distribution of the inclined low-velocity zone in the mantle wedge, particularly its sharp eastern edge (Figure 5). Low-velocity zone is locally thick and there is a large amount of melt. This melt sometimes separates and rises straight in regions of the back-arc side [23]. The activity index distribution map developed in this study and the distribution of the region with a large ratio of decreasing velocity within the low-velocity zones were in good agreement, suggesting high reliability of the activity index distribution map developed for the entire Aomori Prefecture.

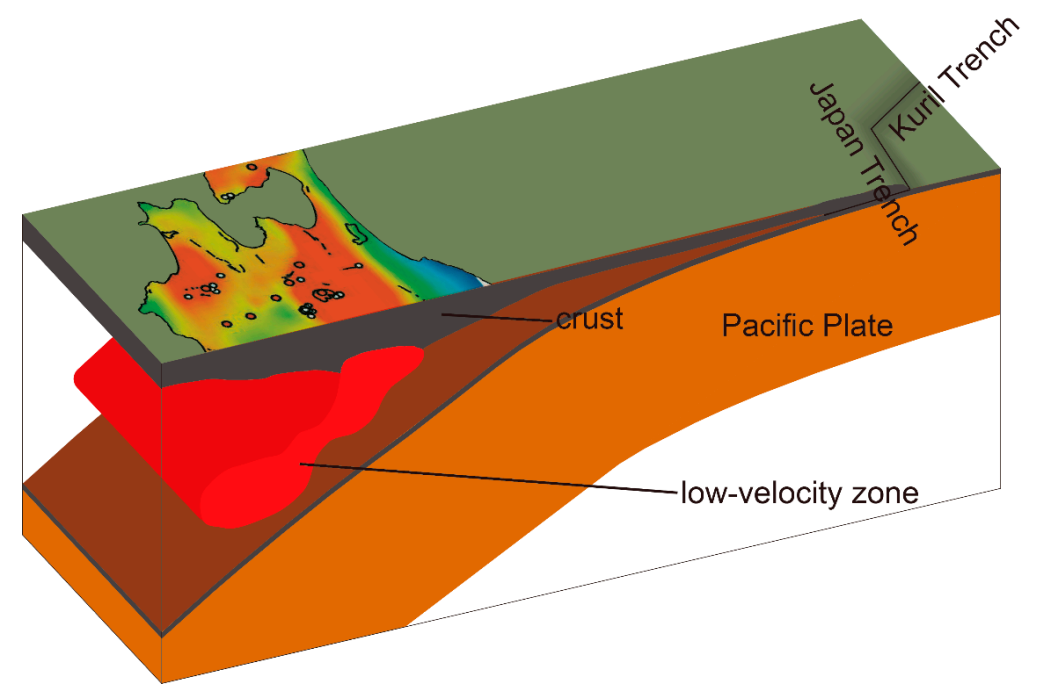

Figure 5. 3D concept model of the crust and upper mantle structure of Aomori Prefecture (modified from Hasegawa et al. [23]).

\subsection{Comparisons between the Activity Index and Solute Geothermometers}

Comparison between the activity index distribution map and temperature distribution, calculated based on those solute geothermometers assumed capable of estimating geothermal reservoir temperature with high precision across Aomori Prefecture, showed that the high activity index areas and high temperature areas were in good agreement. This result gives good indication based on our study results. Therefore, it may be considered that the Hakkoda-san area and Shimokita Peninsula are two areas with potential for geothermal development. Since 2013 after the Great East Japan Earthquake, several geothermal development surveys have been conducted at the Hakkoda-san area 
and Shimokita Peninsula. These surveys are supported economically by Japan Oil, Gas and Metals National Corporation (JOGMEC).

While this study compared the activity index distribution map and temperature distribution map calculated using quartz and Na-K geothermometers, both maps can be considered complementary in the assessment of areas with potential for geothermal exploration. Solute geothermometers are advantageous in that they use chemical data from hot springs, which can be used to estimate geothermal reservoir temperatures based on simple calculations, making them an important tool in current geothermal exploration, but they are flawed because depth is not considered. Conversely, the activity index has the advantage that it can be used to estimate the subsurface thermal structure and thus, it is capable of considering depth, thereby compensating the flaw of solute geothermometers. By combining the conventional method of solute geothermometers with the results derived from the activity index, a more detailed estimation of subsurface thermal structure becomes possible. Therefore, similar to solute geothermometers, the activity index might also become considered as a method useful in the early stages of geothermal exploration because it uses simple calculations with data easily obtainable not only from the wells but also from the natural springs at the ground surface.

\section{Conclusions}

This study developed an activity index distribution map for the entire prefecture was also developed using the Aomori Prefecture Geothermal Resource database, compared it with the distribution of Quaternary volcanoes and the temperature distribution map calculated using quartz and Na-K solute geothermometers. The activity index distribution map for the entire prefecture showed a good fit with both the distribution map of a region with a sharp eastern edge of low-velocity zones in the mantle wedge and the volcanic front, as well as the temperature distribution map calculated using the quartz and Na-K geothermometers. This reflected the effectiveness of the developed map, which indicated the Hakkoda-san and Hiuchi-dake areas as promising for geothermal development.

Acknowledgments: This work was supported by Grant-in-Aid for JSPS Fellows Grant No. 15J10106. We would like to thank Editage (www.editage.jp) for English language editing. This paper benefitted enormously from three anonymous referees' comments.

Author Contributions: Yota Suzuki is a principal investigator of this work so that he has made the geothermal database in Aomori Prefecture, the first manuscript and all the figures. Seiichiro Ioka advised on hydrology and the data quality of the geothermal database. Hirofumi Muraoka co-operatively provided many papers on the geothermal database. All authors read and approved the final manuscript.

Conflicts of Interest: The authors declare no conflict of interest.

\section{References}

1. Bertani, R. Geothermal power generation in the world 2010-2014 update report. Geothermics 2016, 60, 31-43. [CrossRef]

2. Muraoka, H. Summary of the heat source distribution investigation. In Trend and Development Technology of Geothermal Power; Science and Technology: Tokyo, Japan, 2011; pp. 125-137. (In Japanese)

3. Current Situation and Trend of Geothermal Power 2014; Thermal and Nuclear Power Engineering Society: Tokyo, Japan, 2015. (In Japanese)

4. Ministry of the Environment, Japan. The State of Use of Hot Springs in Japan in the Fiscal Year 2012. Available online: http://www.env.go.jp/nature/onsen/data/riyo_h24_1.pdf (accessed on 26 February 2016). (In Japanese).

5. Geothermal Development Research Document, Shimokita Region; New Energy and Industrial Technology Development Organization Report 9; New Energy and Industrial Technology Development Organization (NEDO): Kawasaki, Japan, 1985. (In Japanese)

6. Geothermal Development Research Document, Western Part of Hakkoda Region; New Energy and Industrial Technology Development Organization Report 30; New Energy and Industrial Technology Development Organization (NEDO): Kawasaki, Japan, 1993. (In Japanese) 
7. Geothermal Development Research Document, Shimoyu Region (Part 1); New Energy and Industrial Technology Development Organization Report C-2-12; New Energy and Industrial Technology Development Organization (NEDO): Kawasaki, Japan, 2009. (In Japanese)

8. Geothermal Development Research Document, Shimoyu Region (Part 2); New Energy and Industrial Technology Development Organization Report C-2-12; New Energy and Industrial Technology Development Organization (NEDO): Kawasaki, Japan, 2010. (In Japanese)

9. Hayashi, M.; Taguchi, S.; Yamasaki, T. Activity index and thermal history of geothermal systems. Geotherm. Resour. Counc. Trans. 1981, 5, 177-180.

10. Suzuki, Y.; Ioka, S.; Muraoka, H. Determining the maximum depth of hydrothermal circulation using geothermal mapping and seismicity to delineate the depth to brittle-plastic transition in northern Honshu, Japan. Energies 2014, 7, 3503-3511. [CrossRef]

11. Muraoka, H.; Sakaguchi, K.; Tamanyu, S.; Sasaki, M.; Shigeno, H.; Mizugaki, K. Atlas of Hydrothermal Systems in Japan; Geological Survey of Japan, the National Institute of Advanced Industrial Science and Technology (AIST): Tsukuba, Japan, 2007. (In Japanese)

12. Record of Hot Spring Geology in Aomori Prefecture; Department of Health and Welfare, Aomori Prefectural Office: Aomori, Japan, 1997. (In Japanese)

13. Geothermal Potential Map in Japan; Digital Geoscience Map GT-4 (CD-ROM); Geological Survey of Japan, the National Institute of Advanced Industrial Science and Technology (AIST): Tsukuba, Japan, 2009. (In Japanese)

14. Koga, A.; Hayashi, M. Chemical characteristics of thermal fluids with high geothermal activity index; Part 1. J. Hot Spring Sci. 1986, 37, 14-19. (In Japanese)

15. Hayashi, M. The target for exploration of deep high-temperature geothermal reservoirs. J. Geotherm. Res. Soc. Jpn. 1982, 4, 81-90. (In Japanese)

16. Haas, J.L. The effect of salinity on the maximum thermal gradient of a hydrothermal system at hydrostatic pressure. Econ. Geol. 1971, 66, 940-946. [CrossRef]

17. Wessel, P.; Smith, W.H.F. New, improved version of the generic mapping tools released. Eos Trans. Am. Geophys. Union 1998, 79, 579. [CrossRef]

18. Fournier, R.O. Chemical geothermometers and mixing models for geothermal systems. Geothermics 1977, 5, 41-50. [CrossRef]

19. Giggenbach, W.F. Geothermal solute equilibria. Derivation of Na-K-Mg-Ca geoindicators. Geochim. Cosmochim. Acta 1988, 52, 2749-2765. [CrossRef]

20. Fournier, R.O.; Truesdell, A.H. An empirical Na-K-Ca geothermometer for natural waters. Geochim. Cosmochim. Acta 1973, 37, 1255-1275. [CrossRef]

21. Fournier, R.O.; Potter, R.W. Magnesium correction to the Na-K-Ca chemical geothermometer. Geochim. Cosmochim. Acta 1979, 43, 1543-1550. [CrossRef]

22. Nakajima, J.; Matsuzawa, T.; Hasegawa, A.; Zhao, D. Three-dimensional structure of $V p, V s$, and $V p / V s$ beneath northeastern Japan: Implications for arc magmatism and fluids. J. Geophys. Res. 2001, 106, 21843-21857. [CrossRef]

23. Hasegawa, A.; Nakajima, J.; Kita, S.; Tsuji, Y.; Nii, K.; Okada, T.; Matsuzawa, T.; Zhao, D. Transportation of $\mathrm{H}_{2} \mathrm{O}$ in the NE Japan Subduction Zone as Inferred from Seismic Observations: Supply of $\mathrm{H}_{2} \mathrm{O}$ from the Slab to the Arc Crust. J. Geogr. 2008, 117, 59-75. (In Japanese) [CrossRef]

(C) 2016 by the authors; licensee MDPI, Basel, Switzerland. This article is an open access article distributed under the terms and conditions of the Creative Commons Attribution (CC-BY) license (http://creativecommons.org/licenses/by/4.0/). 